\title{
Black eyes and barriers
}

${ }^{66} \mathrm{~T}$

he degree of civilization in a society can be judged by entering its prisons," Russian literary giant Fyodor Dostoyevsky wrote of his four years spent in exile within a Siberian prison camp.

By that standard, it's hard not to conclude that Canada's provision of treatment for mentally ill inmates is uncivilized, particularly after a recent United Nations Committee Against Torture gave the country failing grades for "inadequate infrastructure of detention facilities to deal with the rising and complex needs of prisoners, in particular those with mental illness."

Among Canada's sins was "the use of solitary confinement, in the forms of disciplinary and administrative segregation, often extensively prolonged, even for persons with mental illness," the committee said in its concluding observations about the nation (http://www2 .ohchr.org/english/bodies/cat/docs/CAT .C.CAN.CO.6.doc).

Its recommendations for improving conditions included measures to reduce overcrowding, to increase capacity to treat prisoners with mental health problems and to abolish the use of solitary confinement for persons with serious or acute mental illness.

The findings were a "very significant" black eye for Canada, which "is consistently in the international spheres claiming to be leaders in health and mental illness for prisoners," says Renu Mandhane, a lawyer and director of the International Human Rights Program in the Faculty of Law at the University of Toronto, Ontario.

The treatment of mentally ill inmates in Canadian prisons is "pretty shocking," adds Mandhane, author of a recent report, Cruel, Inhuman and Degrading? Canada's treatment of federallysentenced women with mental health issues, which charges that the federal government's treatment of female inmates with mental health issues violates international legal obligations (http://ihrp.law.utoronto.ca/sites/ihrp

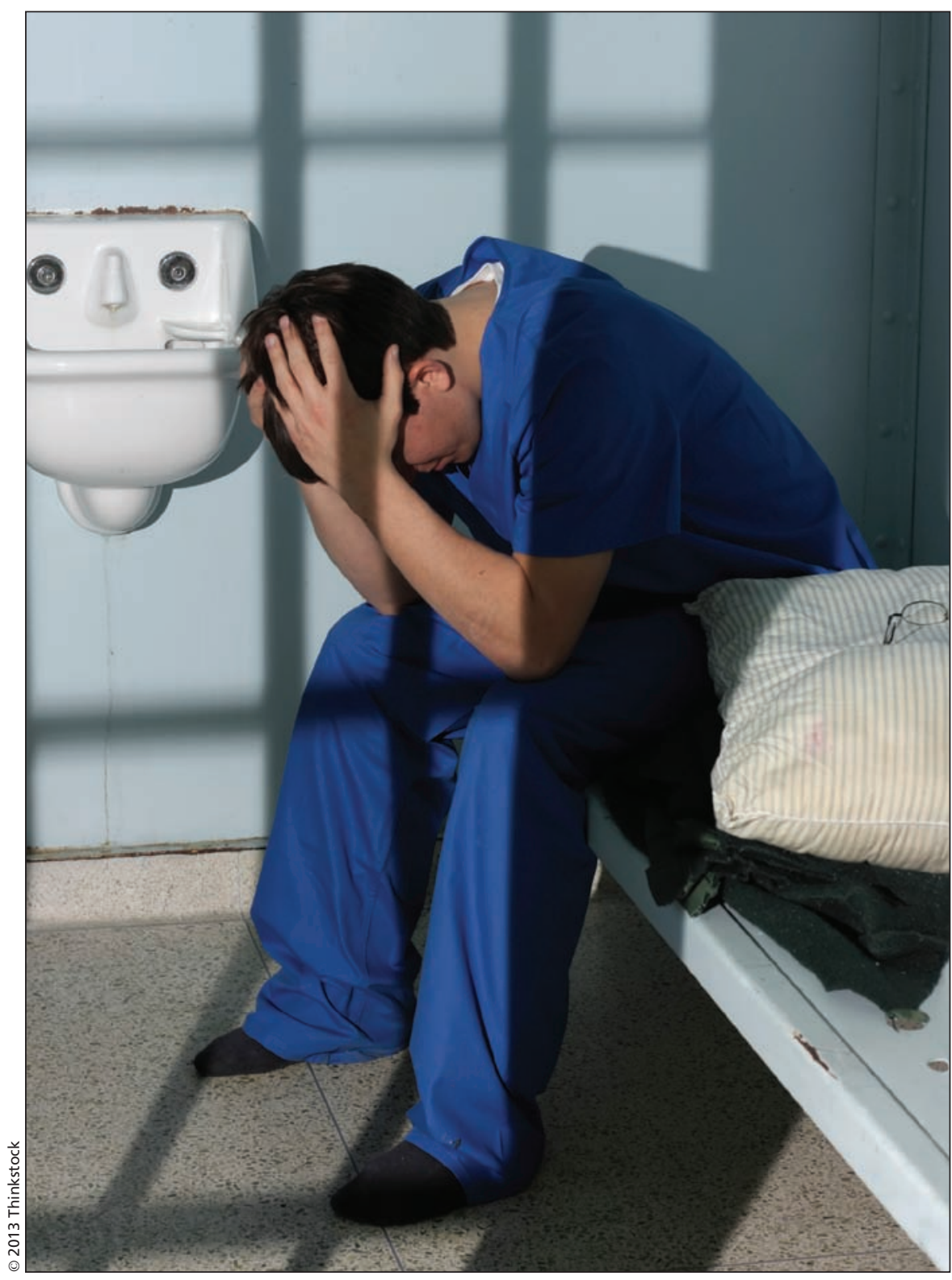

Some critics say that physicians are either reluctant to provide mental services to inmates or pay a price for doing so, which can have a detrimental impact on the patients who are seen.

.law.utoronto.ca/files/documents/Working Group_Clinic/Cruel\%20and\%20Inhuman _FINAL_Print.pdf).

Mendhane's report contends that prisoners with mental health problems are de facto, people with disabilities and therefore, the failure to provide adequate mental treatment violates various provisions of international conven- tions. For example, the overreliance on force and segregation, particularly the use of solitary confinement, constitutes "unlawful deprivation of liberty and security of person" and is therefore a violation of both article 14 of the Convention on the Rights of Persons with Disabilities (www.un.org/disabilities /convention/conventionfull.shtml) and 
article nine of the International Covenant on Civil and Political Rights (http://www2.ohchr.org/english/law/ccpr .htm), the report argues.

But there is, of course, no easy tribunal, either international or domestic, by which substantial improvements might be affected. For the most part, change in the system is entirely a function of political and public opinion, and there isn't an enormous political constituency crying out for more humane treatment of prisoners with mental health problems.

That's an enormous obstacle, argue the advocates for change.

"It's a difficult time, because people are wanting to get tough on crime. As simplistic as that may be, the counter argument is a difficult one to make when you are dealing with victims and victims' families," says Dr. Gary Chaimowitz, head of forensic psychiatry at St. Joseph's Healthcare Hamilton and an associate professor at McMaster University.

"This is an underserved and underrepresented patient population," says Chaimowitz, past-president of the Canadian Academy of Psychiatry and the Law. "This is a population that is facing not only the stigma of mental illness, but also the stigma of violence and a criminal record."

Even worse, adds Chaimowitz, "some of the worst stigmatizers come from within the medical profession itself."

"Within the physicianhood, we don't always practise what we preach," he notes. "There's a fair amount of self stigmatizing that takes place in health care and even in psychiatry, that people who look after patients with serious mental illnesses, people who look after individuals who have committed sexual offenses or who have sexual disorders are sometimes seen more critically than other physicians."

Physicians are either reluctant to provide services to patients or pay a price for doing so, which can have a detrimental impact on the patients who are seen, Chaimowitz notes.

"There's a tendency in the health care system to cherry pick patients. Physicians tend to pick patients who are relatively well, who don't have mental illness, and when you add a criminal history into their profile, these patients are the least likely to be serviced by the outreach provider. They're last on the list of people to be chosen for joining a practice or for getting an appointment."

That can also influence decisions surrounding care, Chaimowitz says. "Many people feel that inpatient psychiatry is not the place for individuals with criminal justice issues, and they should receive their care in corrections facilities rather than in a hospital. Many

people in corrections find it difficult to get their inmates into inpatient psychiatric facilities."

Mandhane is hopeful that the media attention surrounding the inquest into the death by suicide of teenager Ashley Smith will help to sway public and political opinion to improve mental health services for prisoners. "I think it's changed the dynamic. When the tapes were released, there were people who said to me that it totally convinced them that the way we're treating prisoners is actually inhumane. There's something about seeing it with your own eyes. It shocked the conscious of many Canadians who do not necessarily see themselves as pro-prisoners' rights."

"A lot of the solutions are wellresearched and quite apparent, they just need a political will," says Mandhane, adding that "there's a danger to being complacent because we're Canada. We have significant resources, and if we can't protect the human rights of our most marginalized population, then that actually is a serious problem." Nathan Stall MD, Toronto, Ont.

CMAJ 2013. DOI:10.1503/cmaj.109-4392

Editor's note: Fourth of a multipart series on health in the hoosegow.

Part I: Health and hard time

(www.cmaj.ca/lookup/doi/10.1503/cmaj.109-4389).

Part II: Imprisoning the mentally ill

(www.cmaj.ca/lookup/doi/10.1503/cmaj.109-4390).

Part III: Agony behind bars

(www.cmaj.ca/lookup/doi/10.1503/cmaj.109-4391). 